\title{
THEORETICAL AND LEGAL FOUNDATIONS OF ROAD SAFETY
}

\section{Popovich Ye. M.}

\section{INTRODUCTION}

Ensuring road safety (hereinafter-ERS) is one of the leading tasks of the state, which is designed to protect the life and health of citizens, economic development, and integration into the global road transport system. The main negative factor of road traffic injuries (hereinafter-RTI) is the death and injury of people.

\section{Road Safety as an object of administrative and legal regulation in Ukraine}

Today in the world, many factors and factors affect the security of existence and life of humanity. Civil law considers the vehicle (hereinafterthe vehicle) as a source of increased danger (Art. 1187 of the civil code of Ukraine). The state standard of Ukraine 2293-99 provides the following definition of the term danger is a potential source of harm (that is, physical damage and (or) losses caused to human health and (or) property or the environment), so safety is a state of protection of the individual and society from the risk of suffering such damage ${ }^{1}$. The main problem for ERS is road traffic injuries.

ERS is a major global health problem that requires concerted efforts to prevent it effectively and sustainably.

The problems of deterministic ERS a wide range of factors that represent different manifestations of individual-social life: business, Economics, management, psychology, education, law enforcement etc. T. Gurzhiy said that the condition of ERS indirectly affect most areas (fields, sectors), which defines the conditions of human existence, and, thus, largely determines the economic situation, welfare state, welfare of the population. As a social phenomenon, ERS combines a number of components, namely social, legal, institutional, technical, economic, delict and scientific components. The absence of even one of them, according to J. Collier eliminates the content of this phenomenon. So, the problem of ERS is multifaceted and extremely complex. The variety of causes and conditions of an accident requires the

\footnotetext{
${ }^{1}$ Koller Y. road Safety: the main components. Road safety: legal and organizational aspects: proceedings of IX international. sciences'.- pract. Conf. (M. Kiev, 12 listop. 2014). K., 2014. P. 40-45.
} 
development and implementation of a whole range of measures for the organization of traffic (hereinafter - ERS), improvement of road conditions, technical condition of the vehicle, etc ${ }^{2}$. Soviet-era scientists such as. V. Lukyanov, Y. Shelkov believed that a prerequisite for effective influence on the process of traffic in order to ensure its safety is to identify patterns that determine the impact of various factors on the occurrence of accidents and the severity of their consequences. Before all experts, one way or another associated with urban traffic, there is a difficult problem of creating optimal conditions for the coexistence of transport and urban residents. V. Polukarov and O. Shalatov the solution to the problem of ensuring ERS in cities, as well as increasing the capacity of street networks, was seen in improving the ERS at street intersections.

V. Domashenko at the forefront of the definition of "road traffic" puts such a sign as regulatory regulation. Back in the 70s of the last century, a leading scientist in the field of ERS V. Lukyanov noted that the actions of participants in the process of movement of the vehicle on the roads (road traffic) are determined by special rules ${ }^{3}$. In our previous studies, we have also repeatedly noted the legal component of the road traffic process ${ }^{4}$. Finally, R. Mikhailov defines road traffic as a regulated activity that has a social character.

So, in the simplest sense, traffic is the process of mechanical movement of an individual vehicle. TS is like a small molecule- "a particle of a simple or complex substance capable of independent existence, having its basic properties, which are determined by its composition and structure", which must move according to certain General rules. In the absence of movement at least one moving vehicle will not be an accident (it can be any other incident, but not an accident). However, in the expanded definition of the term "road traffic" we already mean not only the movement of an individual physical or mechanical body (be it a pedestrian or a car), but the totality of all components of the system "driver (person) - car-road-environment" (hereinafter CRE) in their interaction. In this case, the traffic will be two integral components, call them: a) static (material) component-the objects of the material world - the same elements of the system "CRE"; b) dynamic

${ }^{2}$ Beschastny V. Public administration in the field of road safety: Monogr. D.: DUI ldos of them. E. Didorenko, 2011.473 p.: tab., rice.

${ }^{3}$ Mutsko V. Administrative and legal regulation of road safety in Ukraine: dis. ... Cand. Yuri. Sciences: 12.00.07 / NATs. Univ of life and environmental Sciences of Ukraine. K., 2011. $198 \mathrm{sec}$.

${ }^{4}$ Ryabko A. Social control and its legal forms (questions of theory): dis. ... cand. yuri. sciences: 12.00.01 / In-t legislator. and compare. lawyer. under Rules. RF. Moscow, 1995. $187 \mathrm{p}$. 
(formal) component-relations, in other words, social relations arising from the formation, existence and interaction of these components. In this sense, the organization and process of road traffic does not depend only on the movement of its individual participant, but exists before, during and after its completion, and has a regulated, more or less predictable nature. The regulatory impact is aimed at ensuring all the criteria that we indicated earlier (efficiency, convenience, safety). But, taking into account today the consequences for society of such a negative factor of traffic as accidents, it is safety that should take the first place among other priorities.

Material and non-material goods, about which there are legal relations are the object of legal regulation (law). Types and volume of material and non-material benefits, which constitute the object of legal regulation, are determined by the legislator and are fixed in laws and other normative-legal acts. A. Soldatov supports the opinion that public relations constitute the object of legal regulation ${ }^{5}$. Thus, public relations that are associated with traffic, as well as with its safety is the object of legal regulation. The peculiarity of the sphere of ensuring ERS, as noted by V. Beschastny, is that it is governed mainly by the rules of administrative law, if the issues of settlement of internal and external relations in the process of ensuring ERS are considered. Under the object of administrative and legal regulation, it is necessary to consider the range of public relations arising in connection with the use of material and intangible benefits, as well as the state-power influence of authorized bodies in order to ensure the legal protection of these benefits ${ }^{6}$. In our case, the boon is the ERS and the associated expected outcomes (some of which we listed in the previous paragraph of this unit).

The state ensures the vital activity of society as a system through the use of power, and the law - through regulatory regulation. A. Skakun under legal regulation proposes to understand carried out by the state with the help of law and a set of legal means the ordering of public relations, their legal consolidation, protection and development. Legal regulation covers various aspects of public life, and legal forms acquire the main and most important types of public relations in various spheres of human activity, which require not just a legislative form, but its substantive legal content. In this regard, special legal knowledge about the features and manifestations of law, legal regulation and provision, achieved by jurisprudence, allow us to better

\footnotetext{
${ }^{5}$ Sopilnik L. Theory and practice of administrative and legal regulation of road safety in Ukraine: dis. ... d-ra yurid. sciences: 12.00 .07 / Kharkiv. NATs. UN-t EXT. cases'. H., 2012. 422 p.

${ }^{6}$ Mutsko V. Administrative and legal regulation of road safety in Ukraine: dis. ... cand. yuri. sciences: 12.00.07 / NATs. Univ of life and environmental Sciences of Ukraine. K., 2011. $198 \mathrm{sec}$.
} 
understand those social processes that are subject to legal influence from the state and require their legal ordering with simultaneous filling of its legal content.

Administrative and legal relations in the vast majority of cases provide for the subordination of the will of managed objects to the dominant will of the managing entity, which the state in accordance with the established procedure confers the appropriate regulatory powers. Thus, the administrative and legal regulation of the ERS contains the same General features that were given above. We can still talk a lot about the content and some aspects of administrative and legal regulation in General, in order to find out as fully as possible the features of this legal phenomenon in the field of ERS. However, in the administrative-legal theory such works already exist and correspond, in our opinion, to those necessary requirements which are put forward by science today. Given the fact that the object of influence in our case is ERS, we propose to take the author's definition as the basic one. The muck, which is under administrative-legal regulation of road safety believes the process of applying the public authorities of special methods of influence on the functioning of public relations concerning the movement of people and goods by vehicle to minimize risk of harm to the life, health, property and other rights of the members of the movement, as well as reducing the number and severity of accidents. The definition proposed By Y. Kogut deserves attention. Considering the peculiarities of administrative legal regulation of activities of local police, the scientist concludes that the impact of law on social relations in the sphere of administrative activity of its bodies through legal means, through a system which ensures the development of relations in the framework and areas of law. Considering the views given by scholars, we can assume that administrative-legal regulation of road safety the effect of law on social relations in this area (which actually are the subject of such regulation) by legal means, through a system which ensures predictable (expected) the development of relations in the framework and areas of law (functioning of the road with a minimized risk of fatal or other serious consequences).

Therefore, V. Donenko assigns the right (legal regulation) the main place in the regulation of relations in the field of $\mathrm{ERS}^{7}$. We also believe that legal regulation is a fundamental condition of relations in the field we are exploring. However, the format in which such regulation should be implemented today in Ukraine needs to be transformed. V. Kovalev sees the definition of the term "transport security" as a state of protection of vital interests of a person and a

${ }^{7}$ Donenko V. Public administration of traffic safety: dis... d-RA yurid. Sciences: 12.00.07 / Dnipropetrovsk. state University EXT. cases'. Dyne., 2012. 436 p. 
citizen, society and the state, objects and subjects of transport infrastructure, which ensures its sustainable development, timely identification, prevention and neutralization of real and potential threats to national interests. In The End V. Mutsko proposes the following definition of ERS - is the state of functioning of public relations regarding the movement of people and goods by means of the vehicle, in which the risk of harm to life, health, property and other rights of participants of such a movement is minimized ${ }^{8}$. Suitable is the expression of M. Dolgopolova about the fact that the accident rate is an indicator of the effectiveness of public administration in the organization of activities to ensure ERS. This activity brings together Executive authorities of all levels, law enforcement agencies and individual sectors of the national economy (automotive, road construction, utilities, education, health care, mass media) into a single social system. The legal definition of the term "national security" draws attention to the fact that the legislator sees " the protection of vital interests of man and citizen, society and the state through the provision of this state by the state (article 1 of the Law of Ukraine "on the basis of national security of Ukraine").

In our opinion, the predictability of road safety will depend on the effectiveness and balance of the regulatory impact of the competent subjects of state administration in the field of road traffic. Thus, in 1997, the Swedish Parliament passed a law on road safety, which fixed the so-called "Concept of zero mortality". The law envisioned the launch of a project that brought together a large number of companies engaged in road construction, automotive, safety, services; as well as the introduction of measures to eliminate road deaths and injuries in road accidents in General. The result proved the authors of the concept right-today only three out of 100 thousand Swedes die as a result of an accident. Due to the implementation of the State target program to increase the level of ERS in Ukraine for the period up to 2016 (expired on the basis Of the resolution of the Cabinet of Ministers No. 71 of 05.03 .2014 ), its authors predicted "reduction of accident rates relative to social risk - from 10.6 to 7.5 ; transport risk-from 33.2 to 18 ". In other words, subject to the implementation of the planned organizational, legal, engineering and other socio-economic measures, the Government and the public of the country expected positive tangible and intangible results: reducing the number of deaths, economic losses from road accidents, improving transport culture and discipline, confidence of road users in their safety (minimizing risks), reducing social tension in society through large losses from road traffic accidents, and so on.

\footnotetext{
${ }^{8}$ Mutsko V. Administrative and legal regulation of road safety in Ukraine: dis. ... cand. yuri. sciences: 12.00.07 / NATs. Univ of life and environmental Sciences of Ukraine. K., 2011. $198 \mathrm{sec}$.
} 
In the draft law of Ukraine "on road traffic and its safety" (in early 2018, the bill was returned for revision to the initiator of the introduction), its drafters offer the following definition of the term " road safety"

- this is the state of the process (system) of road traffic, which determines the degree (level) of protection of road users from accidents and their consequences ${ }^{9}$. Based on the available research of other scientists and specialists, we will try to outline the defining features of ERS. First, it is the level of security - a formal indicator (absolute or relative statistics) of the state of traffic. Secondly, it is a real feeling of society, the population of the country, each individual participant of traffic of protection from threat to become a victim of road accident. Thirdly, it is the defining principle of the organization of traffic as public relations (for example, a person may not always be comfortable to use seat belts while driving in the vehicle, but it is safer, or reducing capital costs by reducing the activities in the design of roads, streets, affecting the ERS, is prohibited). Fourth, it is a systematic activity of authorized entities, which is aimed at identifying and eliminating or leveling (minimizing) the possible risk from negative factors. The latter feature is missing in the definition of the concept of ERS, which is proposed by the authors of the new bill "On road traffic and its safety". But we are sure that this trait is decisive in the end, because the effectiveness of this activity depends on the result of countering $\mathrm{RTI}^{10}$.

Earlier, we stressed that the effectiveness of the state's influence on the level of ERS is as sufficient as the state applies the tools of influence. At the same time, it is clear that an infinite increase in the volume of such "tools" is impossible. Under such conditions, the most important direction of the current stage of political and legal reforms in Ukraine is the creation of an effective administrative and legal mechanism to combat accidents in transport. The effectiveness of the legal impact on public relations in the field of public administration in the field of transport depends not only on the nature and characteristics of these relations, not only on the correctly found method of legal regulation, but also on the successful use of all elements of such a mechanism by which the state-normative will is translated into the actual behavior of subjects of public relations ${ }^{11}$.

\footnotetext{
${ }^{9}$ Gurzhiy T. state policy of road traffic safety-theoretical, legal and organizational bases: dis. ... doctor. Yuri. Sciences: 12.00.07 / Department of science and innovation of the Ministry of interior of Ukraine. Kiev, 2011. 551 p.

${ }^{10}$ Koller Y. road Safety: the main components. Road safety: legal and organizational aspects: proceedings of IX international. sciences'.- pract. conf. (M. Kiev, 12 listop. 2014). K., 2014. P. 40-45.

${ }^{11}$ Veselov N. Administrative and legal prevention of children's road traffic injuries in Ukraine: monograph. E. Didorenko. Donetsk.: Nord-Press, 2011. 219 p.
} 
Thus, we observe a trend in which the level of protection of road users from dangerous factors (as the main element of the ERS) is a consequence of the activities of a wide range of authorized entities in this area. From the point of view of materialistic philosophy, causation is objective, that is, it exists independently of the consciousness and will of man, and is recognizable. Philosophical category "cause" and "effect" reflect objectively existing causal relationships of the real world. These links are universal. In them, one phenomenon (event, process) is the cause of another phenomenon (effect) - the first precedes the second in time and is a necessary condition or basis for the emergence or change and development of another, i.e., the cause generates an effect. On these philosophical positions the theory of causality (casualness) in criminal law is under construction behind which vision under causal connection it is necessary to understand objectively existing connection between act-action or inaction (the reason) - and socially dangerous consequences (consequence) when action or inaction causes (generates) approach of socially dangerous consequence ${ }^{12}$.

If from the position of the theory of causality to look at traffic, it can be taken as a hypothesis that its safety, as organized and regulated by legal norms phenomenon (public relations) are the result of effective or ineffective activities of authorized subjects of public administration in this area, which are the reason on which its condition depends. This interpretation of the ERS phenomenon clearly demonstrates the dependence of its state on the activities of the state, which should take effective measures in this area through the system of public administration. This critical perception of the conditionality of the state and extent of ERS on the performance of ERS actors increases their responsibility for performance.

The analysis of normative legal acts, state programs, strategies, reports, various publications of scientists and specialists in this field of knowledge allowed us to outline the main activities and activities that constitute, relatively speaking, the ERS system. These include:

1) creation of a unified system of accounting for road traffic and its safety;

2) accounting and analysis of information about accidents and their consequences;

3) carrying out examination of road accident, identification of the reasons and the conditions promoting accident rate;

${ }^{12}$ Budnik S. Administrative and legal support of counteraction to offenses in the sphere of traffic safety: dis. ... Cand. Yuri. Sciences: 12.00.07 / Mirage. Acad. UPR. staff. K., 2013. $225 \mathrm{p}$. 
4) standardization and rationing in the field of traffic;

5) organization and management of traffic;

6) clear definition of requirements to road users, their rights and obligations;

7) training of road users;

8) informing road users about the order and conditions of traffic;

9) determination of requirements for admission to the management of the vehicle;

10)increasing the level of structural safety of the vehicle;

11)revision of operational safety requirements to the technical condition of the vehicle;

12)revision of safety requirements for elements of the road network (hereinafter-WDM);

13)establishment of traffic safety requirements at the opening of bus routes, and during the movement of the vehicle carrying out the transportation of organized groups of people, children, persons in respect of which the state protection, dangerous, heavy and oversized cargo;

14) organization of medical support of road safety;

15) the establishment of legal responsibility for violations in the sphere of road traffic;

16) control and supervision in the field of traffic; preventive work among the population to prevent accidents and the like.

The main directions of improving the mechanisms of state management of transport security should be:

- improvement of the regulatory framework and methods of state regulation aimed at minimizing, preventing and preventing risks in the transport industry; implementation of state standards to control the safety of passenger transportation and the state of the vehicle and infrastructure;

- monitoring of compliance with the rules of operation of the vehicle and infrastructure; prevention of terrorist and sabotage activities;

- elimination, as well as forecasting, prevention and minimization of the consequences of man-made and natural disasters;

- improvement of economic and financial mechanisms for ensuring transport security: public-private partnership; promotion of investments in the development of transport infrastructure;

- development of mechanisms of state regulation of motivation of transport carriers to improve the quality and safety of passenger and freight transport services;

The development of a national ERS strategy that provides clear targets and funding for interventions is a key element of sustainable efforts to prevent ERS. Each country should have a ERS strategy that is multispectral 
- that is, bringing together agencies responsible for transport, health, law enforcement, education and other important sectors, as well as multidisciplinary-that is, integrating both governmental and nongovernmental actors (players). The government should provide sufficient resources for the effective development, implementation and monitoring of the activities included in the national strategy in the field of ERS ${ }^{13}$.

Summing up stated in division, we will place accents on key aspects of administrative and legal regulation of ERS in Ukraine at the present stage: first, despite formal decrease in indicators of ERS the situation on roads of Ukraine cannot be considered satisfactory. This requires drawing attention from the society itself to the problems of traffic safety;

secondly, in the author's vision, the administrative and legal regulation of ERS is the impact of law on public relations in this area through legal means, through the system of which the predicted functioning (within the framework and directions defined by the law) of road traffic with a minimized risk of fatal or other severe consequences is provided;

thirdly, today the administrative and legal regulation of ERS should be carried out in the format of priority of public interest and consolidation of efforts of state authorities, local self-government and the whole society on the institutional principles of parity;

fourth, the quintessence in ensuring ERS should be not formal, but real effectiveness of the activities of authorized subjects of public administration in this area ${ }^{14}$.

\section{Subjects of public administration in the field of road traffic and its safety in Ukraine}

According to American experts, transport infrastructure is an important component of maintaining national security, ensuring competitiveness in the world market, as well as economic growth. These experts take a categorical position that the economic importance of land transport cannot be underestimated. Thus, ensuring the safety and effectiveness of this infrastructure and eliminating deficiencies in the maintenance of roads, bridges, timely overcoming of other obstacles in the transit capacity of the system require commitments from the us Congress on the long-term reform of public transport programs, redistribution of powers, as well as building

${ }^{13}$ Peftiev A. Administrative and legal bases of functioning of motor transport: dis. ... Cand. Yuri. Sciences: 12.00.07 / Donets. Yuri. in-t LUVS them. E. O. Didorenko. Donetsk, 2011. $244 \mathrm{p}$.

${ }^{14}$ Beschastny V. Public administration in the field of road safety: Monogr. D.: DUI ldos of them. E. Didorenko, 2011.473 p.: tab., rice. 
partnerships between all levels of government and the private sector of the economy ${ }^{15}$.

Thus, road traffic must meet the needs of convenience, comfort, stability (minimally dependent on adverse climatic conditions, landscape features of the terrain), speed and the like. However, the safety of road transport, given the high level of risks that carry the threat of uncontrolled traffic, is the priority component that must be taken into account and ensured in the pursuit of all other benefits (mentioned earlier). The above explains that measures to ensure ERS are inseparably linked with other (in this case, conditionally they can be called basic) relationships that are generated in connection with the process of spatial movement of material objects and people using the vehicle. Given the basic vectors of human progress-profit-making, satisfaction of needs, benefits and benefits, the conditions of ERS actually have a secondary role. This is most noticeable at the individual level (for example, an individual road carrier in many cases tends to neglect additional conditions for the safety of passengers for personal cost savings, etc.). This leads to the fact that the issues of ERS should be provided primarily in the public sector of legal relations. Therefore, the mechanism of ensuring ERS and guarantees of its functioning are determined by the level of development of the legal system and economic stability of a particular country.

Thus, the state policy in the field of road traffic and its safety is mainly administrative and legal in nature and is usually implemented through legislation, policy acts and strategic concepts. But, as V. Beschastny notes, no less important role is also played by the subjects of ensuring ERS, on whose coordinated actions the state of accident rate, the level of transport service of the population, the quality of provision of motor transport services, etc.

In Ukraine, a large number of different ministries and departments are involved in ensuring road safety, each of which practically carries out various activities for the prevention of road accidents, develops internal departmental standards related to the solution of this problem and monitors their implementation. However, the process of road traffic is unique, it cannot be organized, if there is no uniformity of sufficiently high requirements to the state of the vehicle (regardless of ownership, departmental affiliation, territory) and to road users. From here, the system of ensuring ERS receives the national character which essence consists that all state and public organizations, their officials have to provide observance of the national standards directed on

\footnotetext{
${ }^{15}$ Sopilnik L. Theory and practice of administrative and legal regulation of road safety in Ukraine: dis. ... d-ra yurid. sciences: 12.00.07 / Kharkiv. NATs. UN-t EXT. cases'. H., 2012. $422 \mathrm{p}$.
} 
prevention of accident and its consequences, and citizens who act as drivers and pedestrians, to observe the established rules ${ }^{16}$.

In the previous paragraph, we found that the effectiveness of these actors determines the state of ERS. The need to improve the existing management system in the field of relations, which is the object of our study has repeatedly become the subject of attention of many Ukrainian experts and scientists. As T. Gurzhiy notes, "a prerequisite for the formation of an effective ERS policy is to determine the range of participants in this process...", subjects of public authority play a pivotal role in shaping the state policy of the ERS ${ }^{17}$. It is the creation of an institutionally separate system of ERS bodies that will help to solve the problems arising in this area.

The basis of motor transport activity, road traffic and its safety is a multifaceted system of public relations. Such relations are intertwined organic web to a number of areas that provide social life of the population, serve the ever-growing needs of humanity, namely: the transport system, urban planning, education, medicine. In addition, these relationships are not permanent. They may continue for a certain period, retain some characteristics as a result of transformation, but constantly experience organizational and other changes. Similar views are expressed by F. Pronevich: "the System of traffic safety management ... it is dynamic because the focus on preventing accidents on roads and minimizing socioeconomic damage from road accidents predetermines its continuous improvement and the search for innovative approaches to solving urgent problems" $" 18$. However, there are certain difficulties regarding the clear definition of the subject composition of the institutional mechanism of the transport system, since it goes beyond the range of state bodies, whose functions include the formation, implementation or control of the execution of state policy in a particular sector of transport, as defined in the regulatory acts defining the status of such bodies (approx. - authors').

The existence of state management in the sphere of ensuring road safety has always existed and must exist in the corresponding relationship in the future, because without it is impossible to achieve the required coordination between a large number of subjects, the main purpose of which is not always

\footnotetext{
${ }^{16}$ Sopilnik L. Theory and practice of administrative and legal regulation of road safety in Ukraine: dis. ... d-RA yurid.Sciences: 12.00.07 / Kharkiv. NATs. UN-t EXT. cases'. H., 2012. $422 \mathrm{p}$.

${ }^{17}$ Gurzhiy T. state policy of road traffic safety-theoretical, legal and organizational bases: dis. ... doctor. Yuri. Sciences: 12.00.07 / Department of science and innovation of the Ministry of interior of Ukraine. Kiev, 2011. 551 p.

${ }^{18}$ On the formation of territorial bodies for the provision of services of the Ministry of internal Affairs: resolution of the KAB. Ministers of Ukraine from 28.10.2015 № 889. Official journal of Ukraine. 2015. 20 listop. No. 90. P. 41.
} 
true of ERS. The vast majority of legal entities (state, municipal and private ownership) is not related to the material and (or) legal responsibility of the state of ERS, so they are not always economically interested in investing in those areas of their activities, which act as components of the ERS. This determines the mandatory participation in these legal relations of public authorities (subjects of management in the field of ERS). Summarizing the views of scientists from different branches of law, there is. The Hetman defines that the state power in Ukraine is a special kind of the power which in an exceptional order solves all-social problems through system of specially created state bodies allocated with the corresponding powers according to their distribution on legislative, judicial and Executive branches of power.

General features inherent in the subjects of management are described in detail in the work of V. Razvadovsky. Among them it is possible to allocate existence of a certain organizational-legal form and state-power powers ${ }^{19}$. In legal science, there are many views on the definition of the subject of management. The variability of such definitions increases if we consider such definitions of the subject in a particular specific area. Thus, A. Stakhov tries to clarify the concept of the security body ${ }^{20}$. Other authors interpret the concepts of subjects of transport management ${ }^{21}$. V. Razvadovsky in his study calls the subjects of state regulation of the transport system ${ }^{22}$. L. Sopilnik proves that the system of subjects of management in the field of ensuring ERS is formed by state (regional, branch) and public (local governments, public organizations) subjects of management ${ }^{23}$. M. Mikityuk formulated the concept of "subject of power relations in the sphere of ERS". B. Burbelo definition of the subject of ensuring ERS carries out thanks to the transfer of more or less general or specific measures (functions) in which

${ }^{19}$ Filippov G. Subjects of public administration in the field of road traffic and its safety (in the conditions of administrative reform in Ukraine in 2014-2016). Legal scientific electronic journal. 2016. No. 2. P. 76-80. URL: http://lsej.org.ua/2_2016/23.pdf (date accessed: 01.06.2017).

${ }^{20}$ Sopilnik L. Theory and practice of administrative and legal regulation of road safety in Ukraine: dis. ... d-ra yurid. sciences: 12.00.07 / Kharkiv. NATs. UN-t EXT. cases'. H., 2012. $422 \mathrm{p}$.

${ }^{21}$ On the formation of territorial bodies for the provision of services of the Ministry of internal Affairs: resolution of the KAB. Ministers of Ukraine from 28.10.2015 № 889. Official journal of Ukraine. 2015. 20 listop. No. 90. P. 41. Razvadovsky V. State regulation of the transport system of Ukraine (administrative and legal problems and their solutions): dis. ... d-ra yurid. Sciences: 12.00.07 / NATs. UN-t EXT. cases'. H., 2004. 508 p.

${ }^{22}$ Filippov G. Classification of subjects of public administration in the field of traffic and its safety in Ukraine. Administrative law and process: history, modernity, prospects of development: materials of all-Ukrainian. sciences'.- pract. Conf. (M. Krivoy Rog, 25 birches. 2016). Kryvyi Rih: DEWI Ministry of internal Affairs of Ukraine 2016. P. 178-184.

${ }^{23}$ Donenko V. Public administration of traffic safety: dis. ... d-ra yurid. Sciences: 12.00.07 / Dnipropetrovsk. state University EXT. cases'. Dyne., 2012. 436 p. 
this subject realizes its administrative and legal status. Of course, the above list of scientist's vision of this issue is not limited.

In determining the subject of administrative and legal prevention of children's road traffic injuries (one of the directions of ensuring ERS), we focused on the following features: a) they can be state and non-state structures; b) the nature of relations between them-interaction or subordination. From this we can draw certain conclusions: the nature of the activities of these entities somewhat goes beyond purely administrative. We have focused our attention on this with good reason. It should be said that today in Ukraine, in the scientific and legal community, the use of the definition of "public administration" or other terms related to this concept (for example, "public security" in the Law of Ukraine "on National police"). Public administration in the administrative law of European countries is defined as a set of bodies and institutions that exercise public power through the implementation of laws, bylaws and other acts in the public interest ${ }^{24}$. Y. Fomin draws attention to the fact that this understanding is relevant for the Ukrainian legal system, of course, taking into account certain national characteristics. Public administration, as a legal category, has two dimensions: functional and organizational-structural. With a functional approach - this is the activity of the relevant structural entities to perform functions aimed at the implementation of the public interest. Such interest in Ukrainian law recognizes the interest of the social community that is legalized and satisfied with the state. Thus, for example, the performance of a law enforcement function by a public administration means the systemic activity of all structural entities that have such a function. V. Kolpakov believes that it is expedient to designate such activity by the term "public administration". In the organizational-structural approach, public administration is a set of bodies that are created for the implementation (realization) of public power. V. Donenko holds the same position in his research ${ }^{25}$.

In Ukrainian law, public power is recognized: a) the power of the people, as a direct democracy; b) state power - legislative, Executive, judicial; c) local self-government ${ }^{26}$. From the above, V. Kolpakov concludes that public power in Ukraine is exercised by such bodies: first, the Verkhovna

${ }^{24}$ Koller Y. road Safety: the main components. Road safety: legal and organizational aspects: proceedings of IX international. sciences'.- pract. Conf. (M. Kiev, 12 listop. 2014). K., 2014. P. 40-45.

${ }^{25}$ Donenko V. Public administration of traffic safety: dis... d-ra yurid. sciences: 12.00.07 / Dnipropetrovsk. state University EXT. cases'. Dyne., 2012. 436 p.

${ }^{26}$ Filippov G. Subjects of public administration in the field of road traffic and its safety (in the conditions of administrative reform in Ukraine in 2014-2016). Legal scientific electronic journal. 2016. No. 2. P. 76-80. URL: http://lsej.org.ua/2_2016/23.pdf (date accessed: 01.06.2017). 
Rada of Ukraine (Parliament), the President of Ukraine (as a power institution), local councils; secondly, all bodies and institutions implementing state power (for example, Executive authorities, courts and others); thirdly, all bodies and institutions implementing local selfgovernment. Thus, the public administration is a system of organizational and structural entities that have legally acquired authority for their implementation in the public interest. L. Shevchenko gives more details about the fact that in a broad sense the "public administration", in addition to public authorities, include those bodies that are not part of it organizationally, but perform functions delegated to them (independent public enterprises and individuals during the exercise of their powers of official bodies). In order to form a complete idea of public administration in General, it is appropriate to give some thoughts on this matter to O. Kuzmenko. The scientist says that the modern legal system tends to a generalized term that would cover the content, nature and features of public administration. In classical administrative and legal science, the term "administration", which means Providence, organization, execution, disposal and control (in this part, the author refers to the already existing views of other scientists) ${ }^{27}$. Within the framework of public administration, the priorities of goals and objectives are changing, the technical system is constantly improving, the dominant role is assigned to the achievement of the goal. Thus, public administration is the activity of public administration to satisfy the General public interests of society.

It is the subjects of public authorities in the field of road traffic as official institutions of power that act as the main conductor in ensuring its (traffic) safety, since they are directly responsible for this sphere, determine its directions, develop and activate mechanisms for its implementation. We prefer to support T. Gurzhiy's views that public administration in the field of road safety should be considered as a single institutional and functional mechanism, United by the General goal-to ensure non-stop reduction of accidents and injuries in road transport ${ }^{28}$. Taking into account the above, we propose to consider the subjects of public administration in this industry as a set of bodies and institutions that exercise public power (within their own or delegated competence) by

${ }^{27}$ Budnik S. Administrative and legal support of counteraction to offenses in the sphere of traffic safety: dis. ... cand. yuri. sciences: 12.00.07 / Mirage. Acad. UPR. staff. K., 2013. $225 \mathrm{p}$.

${ }^{28}$ Gurzhiy T. state policy of road traffic safety-theoretical, legal and organizational bases: dis. ... doctor. Yuri. Sciences: 12.00.07 / Department of science and innovation of the Ministry of interior of Ukraine. Kiev, 2011. 551 p. 
implementing laws, regulations and other actions to meet the public interests of society in a convenient, economical and safe traffic.

Based on the analysis of the current legislation, it can be argued that these entities are a branched, multi-level system and, on the one hand, are consolidated around the solution of common tasks, and on the other - carry out specific activities, according to their functions, status, and competence. It is very difficult to make an exhaustive description of all subjects of public administration in this industry, because given the versatility and diversity of legal relations arising in the process of traffic - and in addition - its provision, in addition, related administrative and tort relations-the list of such bodies and institutions may be too detailed.

Attempts to determine the list of the main subjects of ensuring ERS we observe in the works Of V. Beschastny ${ }^{29}$, I. Budnik ${ }^{30}$, B. Burbel ${ }^{31}$, T. Gurzhiya ${ }^{32}$, S. Gusarov ${ }^{33}$, V. Donenko ${ }^{34}$, Y. Koller ${ }^{35}$, V. Mutska ${ }^{36}$, A. Peftieva ${ }^{37}$, V. Razvadovsky ${ }^{38}$, L. Sopilnik ${ }^{39}$, and the like. Such attempts

${ }^{29}$ Beschastny V. Public administration in the field of road safety: Monogr. D.: DUI ldos of them. E. Didorenko, 2011.473 p.: tab., rice.

${ }^{30}$ Budnik S. Administrative and legal support of counteraction to offenses in the sphere of traffic safety: dis. ... Cand. Yuri. Sciences: 12.00.07 / Mirage. Acad. UPR. staff. K., 2013. $225 \mathrm{p}$.

${ }^{31}$ Burbelo Y. Organizational and legal bases of interaction of subjects of ensuring traffic safety: dis... Cand. Yuri. Sciences: 12.00.07 / Lugansk. state University EXT. cases to them. E. Didorenko-Lugansk, 2011.229 p.

${ }^{32}$ Gurzhiy T. state policy of road traffic safety-theoretical, legal and organizational bases: dis. ... doctor. Yuri. Sciences: 12.00.07 / Department of science and innovation of the Ministry of interior of Ukraine. Kiev, 2011. 551 p.

${ }^{33}$ Gusarov S. Administrative and legal bases of administrative activity of the State automobile inspection of Ukraine on ensuring traffic safety: dis... Cand. Yuri. Sciences: 12.00.07 / Kharkiv. NATs. UN-t EXT. cases'. Kharkiv, 2002. 169 p.

${ }^{34}$ Donenko V. Formation of public administration in the field of road safety. Sciences'. Visn. Dnepropetrovsk. State University EXT. cases'. 2012. No. 1. P. 33-41.

${ }^{35}$ Koller Y. road Safety: the main components. Road safety: legal and organizational aspects: proceedings of IX international. sciences'.- pract. Conf. (M. Kiev, 12 listop. 2014). K., 2014. P. 40-45.

${ }^{36}$ Mutsko V. Administrative and legal regulation of road safety in Ukraine: dis. ... Cand. Yuri. Sciences: 12.00.07 / NATs. Univ of life and environmental Sciences of Ukraine. K., 2011. $198 \mathrm{sec}$.

${ }^{37}$ Peftiev A. Administrative and legal bases of functioning of motor transport: dis. ... Cand. Yuri. Sciences: 12.00.07 / Donets. Yuri. in-t LUVS them. E. O. Didorenko. Donetsk, 2011. 244 p.

${ }^{38}$ Razvadovsky V. State regulation of the transport system of Ukraine (administrative and legal problems and their solutions): dis. ... d-RA yurid. Sciences: 12.00.07 / NATs. UN-t EXT. cases'. H., 2004. 508 p.

${ }^{39}$ Sopilnik L. Theory and practice of administrative and legal regulation of road safety in Ukraine: dis. ... d-ra yurid. sciences: 12.00.07 / Kharkiv. NATs. UN-t EXT. cases'. H., 2012. $422 \mathrm{p}$. 
were made by us, as evidenced by previous publications. However, despite the completeness and thoroughness, generality or detail of such variants of systematization of subjects of ensuring ERS, even the last of them, for today, are not completely objective. This situation is taking place in connection with radical changes in the current legislation, the reform of the Ministry of internal Affairs of Ukraine, the Prosecutor's office, local self-government and territorial organization of power in Ukraine.

Summarized the list of entities of public administration in the field of road traffic and its safety can be put in the form that was proposed by B. Burbelo: a) the Verkhovna Rada of Ukraine; b) President; c) CMU; g) the Central state Executive bodies, having authority in the sphere of ensuring road safety, and their territorial divisions; d) local state administrations, their departments and divisions; e) Prosecutor's office; g) the courts of General jurisdiction; c) local authorities. This list of subjects is mainly based on the norms of the Law of Ukraine "on road traffic". However, even this example of systematization of subjects having public authority in the field of traffic can be subjected to constructive criticism. For example, in the wording of the Law of Ukraine "on the Prosecutor's office", which came into force in 2015, article 2 excluded the function of "General supervision" of compliance with the laws... therefore, the role of its bodies in ensuring ERS (in terms of administrative and legal relations), in our opinion, no longer has a direct expression, as before.

The next step in determining the system of subjects of any relationship is their grouping by certain criteria. We believe that this way certainly enriches the knowledge about the subjects, their specific characteristics, but also gives an idea of the system more or less in General terms.

We are inclined to support the position of T. Gurzhiy in this matter ${ }^{40}$, but with some corrections of our own. Our modern vision of the classification of subjects of public administration in the field of traffic and its safety is based on the following positions: there are subjects that determine the conditions of traffic and the boundaries of the transport system-institutional; there are entities that ensure the implementation or formation of the state policy of ERS at the national (ensuring ERS is the main or one of the main tasks of such entities) and inter-sectoral levels (such entities affect the state of ERS through the administration of related spheres of public relations), as well as local governments on the implementation of delegated powers (in the future

${ }^{40}$ Gurzhiy T. state policy of road traffic safety-theoretical, legal and organizational bases: dis. ... doctor. Yuri. Sciences: 12.00.07 / Department of science and innovation of the Ministry of interior of Ukraine. Kiev, 2011. 551 p. 
- implementation of own extended powers of the community) - as a separate group.

The first group includes the Verkhovna Rada of Ukraine, the President of Ukraine, and the Cabinet of Ministers. In the future, we believe that a special state body should be included in this group - The national Bureau of road safety, which will be entrusted with the main state function of improving and adjusting the unified state policy, as well as unified state target programs in the field of road traffic and its safety by coordinating the activities of ministries, other Central Executive bodies, local governments, enterprises, institutions and public organizations in this matter, and working out relevant legislative changes aimed at improving road traffic and improving its safety.

The second group includes the Ministry of internal Affairs of Ukraine, the national police of Ukraine, the Central Executive authorities that ensure the formation of state policy in the field of transport, road management and management of roads, safety on land transport, education and science, health.

The third group includes such subjects as the Central Executive authorities implementing state policy in the field of supervision (control) in the agro-industrial complex, railway transport, construction, architecture, urban planning and housing and communal services, military administration, which is subordinate to the Armed Forces of Ukraine. The fourth group consists of local governments and their Executive bodies ${ }^{41}$.

According to the authors of the new draft law of Ukraine "on road traffic and its safety - the existing system of improving ERS is unsatisfactory, primitive, slow and inaccurate; the relationship between authorities in the field of ERS is far from clear, responsibility and resources are distributed inefficiently ${ }^{42}$. The presence of these obstacles make it impossible to solve other problems, such as: violation by drivers or other participants of traffic rules (speed, drunk driver, ignoring the requirements of road signs, etc.); non-compliance of roads or technical means of traffic regulation with technical norms and rules; rescue and medical services for victims of road accidents are not sufficiently developed, and their solution will facilitate the implementation of a significant part of the knowledge available to date on effective countermeasures to ensure ERS. This is confirmed by the

${ }^{41}$ Filippov G. Classification of subjects of public administration in the field of traffic and its safety in Ukraine. Administrative law and process: history, modernity, prospects of development: materials of all-Ukrainian. sciences'.- pract. Conf. (M. Krivoy Rog, 25 birches. 2016). Kryvyi Rih: DEWI Ministry of internal Affairs of Ukraine 2016. P. 178-184.

${ }^{42}$ Justification of the need to adopt the Law of Ukraine "on road traffic and its safety" / website UPR. ERS MVD of Ukraine; Segalen. the ERS forum. URL: http://www.sai.gov.ua/ uploads/filemanager/file/redakc\%D1\%96ya-zakonu-pro-dorozhn\%D1\%96i-ruh-ta-iogobezpeku-16.12.15-\%D1\%801.rtf (date accessed: 10.10.2016). 
Document of the European conference of Ministers of transport, held on 26.04.2002 $2^{43}$.

\section{CONCLUSIONS}

The problems of deterministic ERS a wide range of factors that represent different manifestations of individual-social life: business, Economics, management, psychology, education, law enforcement etc. The condition of ERS indirectly affect most areas (fields, sectors), which defines the conditions of human existence, and, thus, largely determines the economic situation, welfare state, welfare of the population. As a social phenomenon, ERS combines a number of components, namely social, legal, institutional, technical, economic, delict and scientific components. The absence of even one of them eliminates the content of this phenomenon. So, the problem of ERS is multifaceted and extremely complex. The variety of causes and conditions of an accident requires the development and implementation of a whole range of measures for the organization of traffic, improvement of road conditions, technical condition of the vehicle, etc. Before all experts, one way or another associated with urban traffic, there is a difficult problem of creating optimal conditions for the coexistence of transport and urban residents.

The existence of state management in the sphere of ensuring road safety has always existed and must exist in the corresponding relationship in the future, because without it is impossible to achieve the required coordination between a large number of subjects, the main purpose of which is not always true of ERS. The vast majority of legal entities (state, municipal and private ownership) is not related to the material and (or) legal responsibility of the state of ERS, so they are not always economically interested in investing in those areas of their activities, which act as components of the ERS. This determines the mandatory participation in these legal relations of public authorities (subjects of management in the field of ERS). Summarizing the views of scientists from different branches of law, there is. The Hetman defines that the state power in Ukraine is a special kind of the power which in an exceptional order solves all-social problems through system of specially created state bodies allocated with the corresponding powers according to their distribution on legislative, judicial and Executive branches of power.

${ }^{43}$ Road transport past, present and future road safety work in ECMT: Doc. according to item 4 "Road transport" of the draft agenda of the Council of Ministers in Bucharest 26.04.2002 / podgotov. Kare Rumar; (neofits. translated from the English.). Bucharest: Europe. Conf. Council of Ministers, 2002. 35 p. 


\section{SUMMARY}

We see improvement of functioning of subjects of public administration in the sphere of ERS in the following.

First, the leading subject of the state policy of road safety is the public administration. In our opinion, this successful statement manages to emphasize the leading role of subjects of public administration in the organization and maintenance of ERS.

Secondly, the multilevel and multifunctional nature of the construction, as well as the tendency to transform the system of public administration in a certain area of social and legal relations requires the formulation of some generalized, formulaic model, in particular in the development of General terms, which is of great importance for the unification of legislative and other regulatory acts. Useful in this should be the definition of the main subjects of public administration in the field of road traffic and its safety At the same time, given the frequent changes in the names of ministries, other Executive authorities, their reorganization, it is reasonable to use the generalized lexical formula "Central Executive authority, which ensures the formation (implementation) of state policy in the field...".

Thirdly, it is necessary to clearly delineate the boundaries of the competence of each of the subjects ERS to determine, relatively speaking, the zone of contact between them, with the aim of eliminating duplication and competition, the implementation of unnecessary functions, the formation of additional extra relations, both on a horizontal level between subjects and on the vertical level, in relations with legal entities and individuals in the private sector.

Fourth, the feasibility of harmonization of certain issues and the introduction of permissive nature in the relations between subjects and between subjects of the object of regulation should be based on the principles of ergonomics and saving financial and material resources, categorically excluding manifestations of making money on the issues of road safety and excessive red tape. Recently, in this direction there were positive trends (changes that were due to the adoption of the Law of Ukraine from 05.07.2011 "About modification to some legislative acts of Ukraine concerning elimination of excessive state regulation in the sphere of motor transportations"; formation at the end of 2015 (instead of registration and examination divisions of SAI) as legal entities of public law of territorial bodies on providing services of the Ministry of internal Affairs and so forth).

Fifthly, the need to improve and adjust the unified state policy, as well as unified state target programs in the field of road traffic and its safety requires effective measures to create a Central public administration body (like European countries), which would coordinate the activities of other subjects 
of ensuring ERS (Central Executive authorities, local governments, enterprises, institutions and public organizations in this matter).

Sixth, in order to create proper competition and improve the quality of relevant services and performance of work, it is necessary to create conditions for attracting and combining the efforts of a large number of companies, research institutions engaged in road construction, automotive, services. To this end, as called for. V. Donenko needs to strengthen the status of private persons in relations with public administration bodies by fair legal regulation of administrative procedure, introduction of new organizational forms and standards of quality of administrative services, improvement of the mechanism of protection of the rights of private persons in relations with public administration.

Seventh, taking into account the processes of European integration and the implementation of Ukraine's legal framework and international experience not only at the level of legislation, but also the activities of public administration bodies, we consider it appropriate to review and redistribute certain functions in the field of road traffic and its safety between the Central Executive authorities. In particular, against the background of the reform of the Ministry of internal Affairs of Ukraine, the formation of the National police in our country, a number of functions that have traditionally been assigned to the police (traffic police units) over time should be delegated to other subjects of public administration in the field of ERS.

Eighth, as part of the reform of local self-government and territorial organization of power in Ukraine in order to improve the efficiency of ODA and its security in the relevant territory, the approximation of administrative and regulatory impact to meet the transport needs of society, it is necessary to review the volume and balance (compliance with the needs and material capabilities, staffing) redistribution of certain powers from the Central Executive authorities (their territorial divisions) of local governments ${ }^{44}$.

It can be stated that significant changes in the way of administrative reform have been taking place in the country recently. The reform of individual power structures-subjects of public administration has a direct impact on relations in the field of road traffic and its safety. What kind of impact this will have on these legal relations in the socio-economic sense will depend on the constant monitoring of the processes that will occur in the state, society, economy, and organizational and legal response to

\footnotetext{
${ }^{44}$ Filippov G. Subjects of public administration in the field of road traffic and its safety (in the conditions of administrative reform in Ukraine in 2014-2016). Legal scientific electronic journal. 2016. No. 2. P. 76-80. URL: http://lsej.org.ua/2_2016/23.pdf (date accessed: 01.06.2017).
} 
negative factors. Thus, the scientific community still faces the task of studying the problems of ERS, which is to transform the achievements that affect the creation of a new doctrine of administrative law, the formation of the category of "public administration", which in a generalized form can be represented in the form of an updated institutional system in the field of ERS.

Given that the subject of our study is the work of patrol police in ensuring traffic safety, we wish to emphasize that the quintessence of this paragraph are: a) determination of the place of the specified service in an updated system of entities of public administration in the field of road safety in the National police and the interior Ministry in the General division of the patrol police is one of the major providers of implementation or the shaping of public policy road safety at the national level; b) taking into account the processes of European integration, we set the task of reviewing the functions and competence of patrol police units in this area (as noted in the paragraph above).

\section{REFERENCES}

1. Road transport past, present and future road safety work in ECMT: Doc. according to item 4 "Road transport" of the draft agenda of the Council of Ministers in Bucharest 26.04.2002 / podgotov. Kare Rumar; (neofits. translated from the English.). Bucharest: Europe. Conf. Council of Ministers, 2002. 35 p.

2. Beschastny V. Public administration in the field of road safety: Monogr. D.: DUI ldos of them. E. Didorenko, 2011.473 p.: tab., rice.

3. Budnik S. Administrative and legal support of counteraction to offenses in the sphere of traffic safety: dis. ... Cand. Yuri. Sciences: 12.00.07 / Mirage. Acad. UPR. staff. K., 2013. 225 p.

4. Burbelo Y. Organizational and legal bases of interaction of subjects of ensuring traffic safety: dis... Cand. Yuri. Sciences: 12.00.07 / Lugansk. state University EXT. cases to them. E. Didorenko-Lugansk, 2011. 229 p.

5. Veselov N. Administrative and legal prevention of children's road traffic injuries in Ukraine: monograph. E. Didorenko. Donetsk.: Nord-Press, 2011. 219 p.

6. Gurzhiy T. state policy of road traffic safety-theoretical, legal and organizational bases: dis. ... doctor. Yuri. Sciences: 12.00.07 / Department of science and innovation of the Ministry of interior of Ukraine. Kiev, 2011. $551 \mathrm{p}$.

7. Gusarov S. Administrative and legal bases of administrative activity of the State automobile inspection of Ukraine on ensuring traffic safety: 
dis... Cand. Yuri. Sciences: 12.00.07 / Kharkiv. NATs. UN-t EXT. cases'. Kharkiv, 2002. 169 p.

8. Donenko V. Public administration of traffic safety: dis... d-ra yurid. Sciences: 12.00.07 / Dnipropetrovsk. state University EXT. cases'. Dyne., 2012. 436 p.

9. Donenko V. Formation of public administration in the field of road safety. Sciences'. Visn. Dnepropetrovsk. State University EXT. cases'. 2012. No. 1. P. 33-41.

10. Koller Y. road Safety: the main components. Road safety: legal and organizational aspects: proceedings of IX international. sciences'.- pract. Conf. (M. Kiev, 12 listop. 2014). K., 2014. P. 40-45.

11. Mutsko V. Administrative and legal regulation of road safety in Ukraine: dis. ... Cand. Yuri. Sciences: 12.00.07 / NATs. Univ of life and environmental Sciences of Ukraine. K., 2011. $198 \mathrm{sec}$.

12. Justification of the need to adopt the Law of Ukraine "on road traffic and its safety" / website UPR. ERS MVD of Ukraine; Segalen. the ERS forum. URL: http://www.sai.gov.ua/uploads/filemanager/file/redakc\%D1\% 96ya-zakonu-pro-dorozhn\%D1\%96i-ruh-ta-iogo-bezpeku-16.12.15-\%D1\% 801.rtf (date accessed: 10.10.2016).

13. Peftiev A. Administrative and legal bases of functioning of motor transport: dis. ... Cand. Yuri. Sciences: 12.00.07 / Donets. Yuri. in-t LUVS them. E. O. Didorenko. Donetsk, 2011. 244 p.

14. Filippov G. Classification of subjects of public administration in the field of traffic and its safety in Ukraine. Administrative law and process: history, modernity, prospects of development: materials of all-Ukrainian. sciences'.- pract. Conf. (M. Krivoy Rog, 25 birches. 2016). Kryvyi Rih: DEWI Ministry of internal Affairs of Ukraine 2016. P. 178-184.

15. Filippov G. Subjects of public administration in the field of road traffic and its safety (in the conditions of administrative reform in Ukraine in 2014-2016). Legal scientific electronic journal. 2016. No. 2. P. 76-80. URL: http://lsej.org.ua/2_2016/23.pdf (date accessed: 01.06.2017).

16. About modification to some legislative acts of Ukraine concerning elimination of excessive state regulation in the sphere of road transport: the Law of Ukraine of 05.07.2011 No. 3565-VI. Sheets Of The Verkhovna Rada Of Ukraine. 2012. No. 5. P. 245.

17. On the formation of territorial bodies for the provision of services of the Ministry of internal Affairs: resolution of the KAB. Ministers of Ukraine from 28.10.2015 № 889. Official journal of Ukraine. 2015. 20 listop. No. 90. P. 41. 
18. Razvadovsky V. State regulation of the transport system of Ukraine (administrative and legal problems and their solutions): dis. ... d-ra yurid. Sciences: 12.00.07 / NATs. UN-t EXT. cases'. H., 2004. 508 p.

19. Ryabko A. Social control and its legal forms (questions of theory): dis.... Cand. Yuri. Sciences: 12.00.01 / In-t legislator. and compare. lawyer. under Rules. RF. Moscow, 1995. 187 p.

20. Sopilnik L. Theory and practice of administrative and legal regulation of road safety in Ukraine: dis. ... d-ra yurid.Sciences: 12.00.07 / Kharkiv. NATs. UN-t EXT. cases'. H., 2012. 422 p.

Information about the author:

Popovich Ye. M.,

Doctor of Law, Professor, Professor at the Department of Administrative, Criminal Law and Procedure, International University of Business and Law 37-A, 49 HGD str., Kherson, 73040, Ukraine 